\title{
Melatonin Receptor
}

National Cancer Institute

\section{Source}

National Cancer Institute. Melatonin Receptor. NCI Thesaurus. Code C17310.

Members of the $G$ protein-coupled superfamily of receptors. Two pharmacologically distinct high affinity melatonin receptors have been identified, Mel1 and Mel2, and Mel1 class receptors Mel1A, Mel1B, and Mel1C have been cloned. Transduce signals via at least two pathways, one inhibiting adenylyl cyclase and the other regulating phospholipide metabolism and calcium concentration. 